\title{
Post-traumatic syringomyelia (cystic myelopathy): a prospective study of 449 patients with spinal cord injury
}

\author{
B Schurch, W Wichmann, A B Rossier
}

\begin{abstract}
Objectives-To assess the incidence of post-traumatic syringomyelia (PTS), to correlate the presence of PTS with its most common signs and symptoms, and to compare results from the Swiss Paraplegic Centre with those reported in the medical literature.

Methods-A total of 449 recent traumatic paraplegic and tetraplegic patients admitted to the Swiss Paraplegic Centre in Zurich between 1 January 1987 and 31 December 1993 were prospectively analysed. Yearly clinical tests with conventional radiographs and additional $T 1$ and $T 2$ weighted images were performed as soon as PTS was diagnosed.

Results-Of these 449 patients 20 patients displayed symptoms of PTS $(4 \cdot 45 \%)$. Ten non-operated patients remained clinically stable (average time: 37 months). Ten worsened-three refused operation, seven were operated on. Mean worsening time was 97 months. Deterioration was closely related to the enlargement of the cyst whereas in operated patients neurological improvement or stabilisation correlated with collapse of the cyst.

Conclusions-Delay between appearance of the first symptoms of PTS and deterioration making surgery necessary may be long (mean five years in the seven operated patients) underlining the need for regular tests. "Slosh" and "suck" mechanisms could explain cyst enlargement as surgical realignement of the spine resulted in a complete cyst collapse in two of the operated patients (normalisation of CSF flow ?). Cord compression, tense syrinx at the fracture site, and kyphosis seemed to be closely linked to the enlargement of the cyst with subsequent further neurological deterioration.
\end{abstract}

(F Neurol Neurosurg Psychiatry 1996;60:61-67)

Keywords: spinal cord injuries; post-traumatic syringomyelia; magnetic resonance imaging

Post- traumatic syringomyelia (PTS) was first described by Bastian. ${ }^{1}$ Spinal cord cavitations after serious spinal cord injury were reported by Strümpell et $a l^{2-4}$ Later reports pointed to the appearance of a progressive ascending myelopathy occurring months to years after This study is dedicated to the late Bernard Williams in recog-
nition of his pioneering and everlasting work on the subject of syringomyelia. spinal cord injuries. ${ }^{5}$ The disorder was reported to occur in $3.2 \%$ of paraplegic and tetraplegic patients. ${ }^{6} \mathrm{New}$ techniques of imaging have replaced oil and gas myelography. Magnetic resonance imaging has now become the technique of choice for early diagnosis of PTS which could explain the increase in reported patients.

The natural evolution of PTS is unforseeable and various forms of development have been described (progressive evolution, acute phase and stabilisation, remission). However, there are few reports dealing with long term follow up in non-operated patients. ${ }^{689}$

The purpose of this study was to analyse prospectively all patients with post-traumatic spinal cord injury, admitted to the Swiss Paraplegic Centre in Zurich between 1 January 1987 and 31 December 1993, to evaluate the incidence of PTS, to correlate the presence of PTS with its most common signs and symptoms, and to compare our results with those reported in the medical literature. Regular MRI was carried out to correlate imaging with clinical evolution in both operated and non-operated patients.

\section{Materials and methods}

Four hundred and forty nine paraplegic and tetraplegic patients were admitted from within four hours to up to three weeks after injury and followed up up until 1 July 1994 . Most of these patients had been seen clinically at least once a year. Conventional radiographs of the injured spine were performed before each MRI study. Kyphosis angle of the spine was measured taking the inferior end plate of the first unbroken vertebra above and below the fracture site. Kyphosis angles of the thoracic and thoracolumbar spine were then compared with normal values. ${ }^{10}$ For the cervical spine all positive angles (kyphosis) were considered as abnormal as under normal conditions the cervical spine is in lordosis. In most patients MRI studies were carried out on the day of the trauma and thereafter yearly after diagnosis of PTS. Osteosynthesis material was removed whenever necessary to allow MRI examinations. In cases of surgical revision of the syrinx, MRI was performed six months after surgery and then yearly. Non-contrast MRI was done using either a $0.5,1.0$, or $1.5 \mathrm{~T}$ superconducting magnet. Spin echo images were obtained as $T 1$ weighted sagittal and axial planes and T2 weighted sagittal planes in most patients. Dual echo sagittal and coronal weighted images were sometimes also performed. 
Table 1 Data, symptoms, and clinical findings of the non-operated patients

\begin{tabular}{|c|c|c|c|c|}
\hline Patients/age/sex & Neurol level & Fracture & Symptoms & Clinical signs \\
\hline \multicolumn{5}{|c|}{ Non-operated patients } \\
\hline $1 / 45 / M$ & C7 incomplete & C5/C6 & Pain & \multirow{6}{*}{$\begin{array}{l}\downarrow \text { Tendon reflexes unilateral } \\
\uparrow \text { Spasticity } \\
\uparrow \text { Sensory level unilateral } \\
\text { (dissociated) } \\
\uparrow \text { Spasticity } \\
\downarrow \text { Tendon reflexes unilateral } \\
\downarrow \text { Tendon reflexes bilateral } \\
\uparrow \text { Spasticity } \\
\uparrow \text { Sensory level unilateral } \\
\text { (dissociated) } \\
\uparrow \text { Motor level unilateral } \\
\downarrow \text { Tendon reflexes unilateral } \\
\text { None }\end{array}$} \\
\hline $3 / 20 / \mathrm{M}$ & T6 complete & $\mathrm{T} 4$ & $\begin{array}{l}\text { Pain } \\
\downarrow \text { Sensitivity }\end{array}$ & \\
\hline $4 / 58 / \mathrm{M}$ & C8 complete & C6, T9 & Pain & \\
\hline 5/57/M & T6 complete & & Pain & \\
\hline $6 / 22 / F$ & T4 complete & T4-5 & $\uparrow$ Muscle weakness & \\
\hline $7 / 16 / \mathrm{M}$ & C7 complete & $\mathrm{C} 4 / \mathrm{C} 5$ & $\begin{array}{l}\text { Pain } \\
\downarrow \text { Sensitivity } \\
\uparrow \text { Muscle weakness } \\
\uparrow \text { Spasticity }\end{array}$ & \\
\hline $8 / 20 / \mathrm{M}$ & T7 complete & T5-6 & Pain & $\uparrow$ Spasticity \\
\hline 9/34/M & C7 complete & $\mathrm{C} 6 / \mathrm{C} 7$ & $\uparrow$ Spasticity & \multirow{6}{*}{$\begin{array}{l}\uparrow \text { Spasticity } \\
\uparrow \text { Sweating } \\
\uparrow \text { Spasticity } \\
\uparrow \text { Sensory level unilateral } \\
\quad \text { (dissociated) } \\
\uparrow \text { Motor level } \\
\downarrow \text { Tendon reflexes unilateral } \\
\uparrow \text { Spasticity } \\
\uparrow \text { Sensory level } \\
\text { (non-dissociated) } \\
\uparrow \text { Motor level } \\
\downarrow \text { Tendon reflexes unilateral } \\
\uparrow \text { Spasticity } \\
\uparrow \text { Spasticity }\end{array}$} \\
\hline $10 / 20 / M$ & T12 incomplete & T12 & None & \\
\hline $12 / 27 / \mathrm{M}$ & T12 complete & T12-L1 & $\begin{array}{l}\uparrow \text { Muscle weakness } \\
\downarrow \text { Sensitivity }\end{array}$ & \\
\hline $18 / 38 / \mathrm{M}$ & T12 complete & $\mathrm{T} 12$ & $\begin{array}{l}\uparrow \text { Spasticity } \\
\text { Numbness } \\
\downarrow \text { Sensitivity }\end{array}$ & \\
\hline $19 / 21 / M$ & L4 complete & Ll 1 & $\uparrow$ Spasticity & \\
\hline $20 / 19 / M$ & C6 complete & $\mathrm{C} 5$ & & \\
\hline \multicolumn{5}{|c|}{ Operated patients } \\
\hline $2 / 30 / \mathrm{M}$ & T5 complete & T4-5-6 & $\begin{array}{l}\text { Pain } \\
\downarrow \text { Sensitivity } \\
\uparrow \text { Muscle weakness }\end{array}$ & \multirow{7}{*}{$\begin{array}{l}\uparrow \text { Sensory level unilateral } \\
\text { (dissociated) } \\
\downarrow \text { Tendon reflexes unilateral } \\
\uparrow \text { Motor level bilateral } \\
\uparrow \text { Sensory level unilateral } \\
\text { (dissociated) } \\
\uparrow \text { Motor level unilateral } \\
\downarrow \text { Tendon reflexes unilateral } \\
\uparrow \text { Spasticity } \\
\uparrow \text { Sensory level bilateral } \\
\uparrow \text { Motor level bilateral } \\
\downarrow \text { Tendon reflexes bilateral } \\
\uparrow \text { Sensory level bilateral } \\
\text { (dissociated) } \\
\uparrow \text { Motor level bilateral } \\
\uparrow \text { Sensory level unilateral } \\
\text { (dissociated) } \\
\uparrow \text { Motor level unilateral } \\
\downarrow \text { Tendon reflexes bilateral } \\
\uparrow \text { Sensory level bilateral } \\
\text { (dissociated) } \\
\uparrow \text { Motor level bilateral } \\
\downarrow \text { Tendon reflexes bilateral } \\
\uparrow \text { Spasticity } \\
\uparrow \text { Spasticity }\end{array}$} \\
\hline $11 / 66 / \mathrm{F}$ & T8 complete & T4, T8-9 & $\begin{array}{l}\text { Pain } \\
\uparrow \text { Muscle weakness }\end{array}$ & \\
\hline $13 / 27 / M$ & C8 complete & $\mathrm{C} 6 / \mathrm{C} 7$ & Pain & \\
\hline $14 / 44 / \mathrm{F}$ & T12 incomplete & $\mathrm{L} 1$ & Pain & \\
\hline $15 / 18 / M$ & C7 complete & $\mathrm{C} 5-\mathrm{C} 6$ & Pain & \\
\hline $16 / 6 / M$ & T2 incomplete & T3-4 & $\begin{array}{l}\text { Dysaesthesia } \\
\downarrow \text { Sensitivity muscle } \\
\uparrow \text { Muscle weakness }\end{array}$ & \\
\hline $17 / 27 / \mathrm{F}$ & T6 complete & T5 & $\begin{array}{l}\text { Pain } \\
\uparrow \text { Spasticity }\end{array}$ & \\
\hline
\end{tabular}

Neurol level $=$ neurological level; C5/C6 means translation fracture C5 with burst fracture C6.

Each of the scans was read successively by two radiologists. Most of the patients were examined with a superficial coil. In some patients, the entire cord was imaged (body coil).

\section{Results}

Out of 449 patients diagnosis of PTS was confirmed by MRI in $20(4.45 \%)$ patients. The average age at the time of trauma ranged from 6 to 66 (mean 32.2) years. Spinal fracture was localised in the cervical or cervicothoracic region in seven patients, in the thoracic region in nine, and in the thoracolumbar region in four. The initial neurological deficit was sensory-motor complete in 16 patients, sensorymotor incomplete in three, and sensory incomplete but motor complete in one.

The time between spinal injury and the appearance of the first symptoms ranged from two months to 30 years (mean $7 \cdot 2$ years). The time from injury to diagnosis of PTS ranged from nine months to 30 years (mean: $9 \cdot 4$ years). The diagnosis was delayed up to 17 (mean 2.3) years after the onset of the first symptoms of PTS. The average lapse of time between injury and the appearance of the first symptoms was $7 \cdot 2$ years (range two months to 30 years) in 16 patients with complete cord lesions and $7 \cdot 7$ years (range 22 months to 20 years) in four patients with partial lesions.

SYMPTOMS AND SIGNS

At the time of the diagnosis the complaints were either single or combined. Only one patient had no complaint. An objective increase in spasticity raised suspicions of PTS in this patient. Table 1 summarises the symptoms, clinical findings, and data of operated and non-operated patients. Pain was the most common symptom. In all 12 patients with pain it was an early finding. Pain character was usually dull aching or burning. Coughing or straining made it worse in almost all patients. Pain was never associated with numbness and 
Table 2 Clinical data, radiographs, and MRI findings with their evolutions in the non-operated and operated patients

\begin{tabular}{|c|c|c|c|c|c|c|c|c|c|c|c|c|c|}
\hline Patients & Kyphosis & $\begin{array}{l}\text { Max } \\
\text { normal } \\
\text { angle }\end{array}$ & $\begin{array}{l}\text { Spinal } \\
\text { displace- } \\
\text { ment }\end{array}$ & $\begin{array}{l}\text { Spinal } \\
\text { canal } \\
\text { narrowing }\end{array}$ & $\begin{array}{l}\text { Cord } \\
\text { compres- } \\
\text { sion }\end{array}$ & $\begin{array}{l}\text { Tense syrinx } \\
\text { at fracture } \\
\text { site }\end{array}$ & $\begin{array}{l}\text { Length } \\
\text { (segments) }\end{array}$ & $\begin{array}{l}\text { Max/ } \\
\text { Lesion }\end{array}$ & $\begin{array}{c}\text { Diam } \\
(\mathrm{mm})\end{array}$ & $\begin{array}{l}\text { Intra- } \\
\text { cavital } \\
\text { septum }\end{array}$ & $\begin{array}{l}\text { Cord } \\
\text { appearance } \\
\text { cyst }\end{array}$ & $\begin{array}{l}\text { Follow up } \\
\text { op } \\
\text { (months) }\end{array}$ & Evolution \\
\hline \multicolumn{14}{|c|}{ Non-operated patients } \\
\hline 1 & Absent & - & Absent & Absent & Absent & Absent & 2 & $\mathrm{C} 4 / \mathrm{C} 7$ & 5 & Absent & Enlarged & 56 & Stable \\
\hline 3 & $39^{\circ} \mathrm{T} 4-5$ & $19^{\circ}$ & Present+ & Absent & Present + & Present+ & 17 & $\mathrm{C} 4-\mathrm{T} 4 / \mathrm{T} 6$ & 12 & Present & Atrophic & 30 & Worse \\
\hline 4 & Absent & - & Present + & Present+ & Absent & Absent & 1 & $\mathrm{C} 6-\mathrm{C} 7 / \mathrm{C} 8$ & 0.5 & Absent & Atrophic & 52 & Stable \\
\hline 5 & $38^{\circ} \mathrm{T} 4-7$ & $38^{\circ}$ & Absent & $+(15 \%)$ & Absent & Present+ & 1 & T5-T6/T6 & 6 & Absent & Atrophic & 47 & Stable \\
\hline 6 & $28^{\circ} \mathrm{T} 4-6$ & $26^{\circ}$ & Present++ & $++(30-40 \%)$ & Present+++ & - Present+++ & 14 & $\mathrm{~T} 2-\mathrm{T} 3 / \mathrm{T} 4$ & $9 \cdot 5$ & Present & Enlarged & 68 & Worse \\
\hline 7 & $10^{\circ} \mathrm{C} 3-6$ & - & Presentt & Present+ & Absent & Absent & 1 & $\mathrm{C} 4-\mathrm{C} 5 / \mathrm{C} 5$ & $5 \cdot 6$ & Absent & Enlarged & 46 & Stable \\
\hline 8 & $22^{\circ} \mathrm{T} 4-6$ & $26^{\circ}$ & Absent & Present+ $(15 \%)$ & Absent & Present+ & 11 & T6-T7/T5 & 6 & Present & Enlarged & 45 & Stable \\
\hline 9 & Absent & & Present+ & Absent & MA & Present+ & 4 & $\mathrm{C} 4-\mathrm{T} 1 / \mathrm{C} 7$ & 7 & Present & $\mathrm{MA}$ & 50 & Stable \\
\hline 10 & $50^{\circ} \mathrm{T} 1-\mathrm{Ll}$ & $25^{\circ}$ & Present +++ & $\begin{array}{l}\text { Absent } \\
\quad \text { (adhesion) }\end{array}$ & Absent & $\begin{array}{l}\text { Absent } \\
\quad \text { (adhesion) }\end{array}$ & 3 & T9-T12/T12 & 8 & Present & Enlarged & 47 & Stable \\
\hline 12 & $20^{\circ} \mathrm{T} 12-\mathrm{L} 1$ & $17^{\circ}$ & Not measure & eable & & $\rightarrow$ & 11 & $\mathrm{~T} 4 / \mathrm{T} 12$ & 10 & Present & Enlarged & 278 & Worse \\
\hline 18 & $13^{\circ} \mathrm{T} 12-\mathrm{L} 1$ & $17^{\circ}$ & Present++ & Present++ & Present++ & Present++ & 10 & $\mathrm{~T} 5-\mathrm{L} 2 / \mathrm{T} 12$ & 8 & Present & Enlarged & 7 & $\begin{array}{c}\text { Worse, } \\
\text { then } \\
\text { stable }\end{array}$ \\
\hline 19 & $22^{\circ} \mathrm{T} 12-\mathrm{L} 1$ & $17^{\circ}$ & Present+ & Present+ & Present+ & Present+ & 1 & $\mathrm{~T} 12-\mathrm{L} 1 / \mathrm{T} 12$ & 4 & Present & Enlarged & 11 & Stable \\
\hline 20 & $12^{\circ} \mathrm{C} 3-\mathrm{C} 7$ & & Present+ & Present+ & Present+ & Present+ & 1 & $\mathrm{C} 4-\mathrm{C} 5 / \mathrm{C} 5$ & 1 & Absent & Enlarged & 7 & Stable \\
\hline \multicolumn{14}{|c|}{ Operated patients (preoperative status) } \\
\hline 2 & $69^{\circ} \mathrm{T} 4-7$ & $38^{\circ}$ & Present+++ & Present +++ & Present ++ & Present+++ & 17 & $\mathrm{C} 2-\mathrm{T} 12 / \mathrm{T} 6$ & 13 & Present & Enlarged & 65 & Worse \\
\hline 11 & $25^{\circ} \mathrm{T} 4-5$ & $17^{\circ}$ & Present+++ & Present++ & Present++ & Present+++ & 10 & T3-T10/T8-T9 & 9 & Present & Enlarged & 66 & Worse \\
\hline 13 & $25^{\circ} \mathrm{C} 4-7$ & - & Present++ & Present++ & Present+ & Present+ & 11 & $\mathrm{~T} 1 / \mathrm{C} 6-\mathrm{C} 7$ & 5 & Present & Atrophic & 288 & Worse \\
\hline 14 & $45^{\circ} \mathrm{T} 12-\mathrm{L} 2$ & $20^{\circ}$ & Present++ & Present++ & Present+ & Present+++ & 4 & $\mathrm{~T} 12 / \mathrm{L} 1$ & 13 & Present & Atrophic & 53 & Worse \\
\hline 15 & $18^{\circ} \mathrm{C} 3-\mathrm{C} 7$ & - & Absent & Absent & Present++ & Present++ & 4 & C7-T1/C5-C6 & 15 & Absent & Atrophic & 360 & Worse \\
\hline 16 & $28^{\circ} \mathrm{T} 3-4$ & - & Present++ & Present+ & Not measur & eable (bad qual & lity) & & & $\rightarrow$ & $\rightarrow$ & 444 & Worse \\
\hline 17 & $30^{\circ} \mathrm{T} 4-6$ & $26^{\circ}$ & Present +++ & Present++ & Present++ & Present++t & 5 & $\mathrm{~T} 4-5 / \mathrm{T} 6$ & 9 & Present & Atrophic & 9 & Worse \\
\hline
\end{tabular}

Max normal angle $=$ maximal normal spine angle described by Stagnara. ${ }^{10}$ For the cervical spine all positive angles were considered as abnormal as under normal conditions the cervical spine is in lordosis; Cord compression $=$ cord compression at the fracture site; Length = total length of the syrinx; $m a x / L$ esion $=$ maximal PTS conditions the cervical spine is in lordosis; Cord compression = cord compression at the fracture site; Length = total length of the syrinx; max/Lesion = maximal PTS
diameter compared with the level of the myelomalacic core; Diam = maximal PTS diameter; Follow up = follow up up to diagnosis of PTS; Follow up op = follow diameter compared with the level of the myelomalacic core;
up from PTS diagnosis to surgery; MA = material artefact.

the only two patients with numbness had no pain. Pain was located at or above the site of the original spinal injury in 10 patients and below it in two (one complete, one incomplete paraplegic). Pain at or below the level of cord lesion was indistinguishable from the usual phantom or neurogenic pain. Pain at or above the level of the cord lesion was easier to assess. It was unilateral in nine patients and bilateral in one patient.

The most common clinical signs were sensory disturbances and modification of the deep tendon reflexes. Out of 20 patients 10 showed a symmetric or asymmetric ascending sensory level. Dissociation between pain and touch was seen in eight patients. A sensory ascending level was never found as a single clinical finding. All 10 patients with such a deficit also had decreased deep tendon reflexes in the upper or lower limbs. Depression of reflexes was unilateral in most of the patients. Seven patients went to the centre because of increased motor deficit. Worsening of motor function was found clinically in nine patients and was always combined with other symptoms.

Table 3 Initial treatment, MRI findings, neurological evolution, and follow up since PTS diagnosis in non-operated patients

\begin{tabular}{|c|c|c|c|c|c|}
\hline Patients & $\begin{array}{l}\text { Initial } \\
\text { treatment } \\
\text { (postinjury) }\end{array}$ & $\begin{array}{l}\text { MRI at } \\
\text { diagnosis }\end{array}$ & $\begin{array}{l}\text { MRI at } \\
\text { follow up }\end{array}$ & $\begin{array}{l}\text { Neurological } \\
\text { evolution }\end{array}$ & $\begin{array}{l}\text { Follow up/ } \\
\text { PTS diagnosis } \\
\text { (months) }\end{array}$ \\
\hline 1 & $\begin{array}{l}\text { Operative } \\
\text { stabilisation }\end{array}$ & Syrinx C4-C6 & Unchanged & Stable & 56 \\
\hline 3 & Conservative & Syrinx C2-T10 & Small increase & Worse & 30 \\
\hline 4 & Conservative & Syrinx C6-C7 & Unchanged & Stable & 52 \\
\hline 5 & Conservative & Syrinx T5-T6 & Unchanged & Stable & 47 \\
\hline 6 & $\begin{array}{l}\text { Operative } \\
\text { stabilisation }\end{array}$ & Syrinx C1-T7 & Increased & Worse & 68 \\
\hline $\begin{array}{l}7 \\
8\end{array}$ & $\begin{array}{l}\text { Conservative } \\
\text { Conservative }\end{array}$ & $\begin{array}{l}\text { Syrinx C4-C5 } \\
\text { Syrinx T2-T12 }\end{array}$ & $\begin{array}{l}\text { Unchanged } \\
\text { Unchanged }\end{array}$ & $\begin{array}{l}\text { Stable } \\
\text { Stable }\end{array}$ & $\begin{array}{l}46 \\
45\end{array}$ \\
\hline 9 & $\begin{array}{l}\text { Operative } \\
\text { stabilisation }\end{array}$ & Syrinx C4-T1 & Unchanged & Stable & 50 \\
\hline 10 & $\begin{array}{l}\text { Operative } \\
\text { stabilisation }\end{array}$ & Syrinx T9-T12 & Unchanged & Stable & 47 \\
\hline 12 & Conservative & $\begin{array}{l}\text { Syrinx C2-T4 } \\
\text { (below not explored) }\end{array}$ & Increased & Worse & 278 \\
\hline $\begin{array}{l}18 \\
19\end{array}$ & $\begin{array}{l}\text { Conservative } \\
\text { Conservative }\end{array}$ & $\begin{array}{l}\text { Syrinx T5-L2 } \\
\text { Syrinx T12-L1 }\end{array}$ & $\begin{array}{l}\text { Unchanged } \\
\text { Unchanged }\end{array}$ & $\begin{array}{l}\text { Stable } \\
\text { Stable }\end{array}$ & $\begin{array}{r}7 \\
11\end{array}$ \\
\hline 20 & $\begin{array}{l}\text { Operative } \\
\text { stabilisation }\end{array}$ & Syrinx C4-C5 & Unchanged & Stable & 7 \\
\hline
\end{tabular}

An increase in spasticity below the level of the lesion was present in 12 patients. In six of these increased spasticity was the single objective finding of PTS.

Facial sensory deficit, Horner's syndrome, and decreased breathing when sitting were never seen.

\section{RADIOLOGICAL FINDINGS \\ Radiographs}

Cervical spine-Out of seven lateral radiographs taken in a neutral position (as much as it was technically feasible) four showed a kyphosis at the time of diagnosis of PTS. Kyphosis angle varied between $10^{\circ}$ and $25^{\circ}$ $\left(10^{\circ}, 12^{\circ}, 18^{\circ}, 25^{\circ}\right.$; table 2$)$. At follow up two of these four patients required surgical drainage of the cyst (table 3). Kyphosis angle remained unchanged after surgery. The neurological condition of the other two patients remained stable during a follow up time of seven and 46 months (tables 2, 3, and 4). Spinal alignment was within physiological limits in the other three patients whose neurological condition remained unchanged during their follow up (see tables 2, 3, and 4).

Thoracic and thoracolumbar spine-Out of 13 lateral radiographs 10 showed an abnormal kyphosis at the time of diagnosis of PTS. At follow up eight out of these 10 patients showed a neurological deterioration. Five of them were operated on and they improved. Three refused operation with further neurological worsening. The neurological condition of the five remaining patients did not show any further change (see tables 2,3 , and 4 ).

\section{Magnetic resonance imaging}

Fifty two MRI studies were carried out on the 20 patients with PTS. When multiple examinations were needed mean interval time between two examinations was 11.5 (range 1-60) months 
Table 4 Initial treatment, MRI findings, neurological evolution, and follow up since diagnosis of PTS in operated patients

\begin{tabular}{|c|c|c|c|c|c|c|c|c|}
\hline Pationts & $\begin{array}{l}\text { Initial } \\
\text { treatment } \\
\text { (postimjury) }\end{array}$ & $\begin{array}{l}\text { MRI at } \\
\text { diagnosis }\end{array}$ & $\begin{array}{l}\text { MRI at } \\
\text { follow up }\end{array}$ & $\begin{array}{l}\text { Neurological } \\
\text { evolution }\end{array}$ & $\begin{array}{l}\text { Follow up } \\
\text { trauma } \\
\text { (months) }\end{array}$ & Operation & $\begin{array}{l}\text { MRI after } \\
\text { surgery }\end{array}$ & $\begin{array}{l}\text { Neurological } \\
\text { evolution }\end{array}$ \\
\hline 2 & Conservative & Syrinx C1-T10 & Syrinx whole cord & Worse & 68 & Restabilisation of the spine & Collapse of cyst & Better \\
\hline 11 & Conservative & Syrinx T2-T11 & Syrinx C2-T12 & Worse & 83 & $\mathrm{~T}$ tube & Collapse of cyst & Better \\
\hline 13 & Conservative & Syrinx C3-C6 & Syrinx $\mathrm{C} 2-\mathrm{T} 6$ & Worse & 314 & Syringostomia & Collapse of cyst & Stable \\
\hline 14 & $\begin{array}{l}\text { Operative } \\
\text { stabilisation }\end{array}$ & Syrinx T8-T11 & Syrinx T7-L1 & Worse & 79 & Restabilisation of the spine & Collapse of cyst & Better \\
\hline 15 & Conservative & Syrinx C1-T1 & Syrinx C. $3-\mathrm{T} 1$ & Worse & 386 & T tube & Collapse of cyst & Better \\
\hline 16 & Conservative & Syrinx C4-T1 & Syrinx C4-T1 & Worse & 470 & Syringostomia & Collapse of cyst & $\begin{array}{l}\text { Better, } \\
\text { then worse }\end{array}$ \\
\hline 17 & Conservative & Syrinx T1-T6 & Syrinx T1-T7 & Worse & 35 & T tube & Collapse of cyst & Better \\
\hline
\end{tabular}

The following variables were investigated: (a) spine displacement; (b) spinal canal narrowing; (c) cord compression; (d) tense syrinx at the fracture site (bow shaped); (e) length of the syrinx; $(f)$ site of the maximal syrinx diameter in relation to the fracture site; $(g)$ maximal diameter in $\mathrm{mm}$; $(h)$ septa; $(i)$ cord appearance at the level of the cyst.

From these criteria the following findings were noted (table 2):

(1) All patients showing worsening of their neurological condition displayed simultaneously pronounced cord compression, tense syrinx at the fracture site, and kyphosis.

(2) Spine displacement and narrowing of the spinal canal seemed to be of importance as long as they were associated with cord compression.

(3) A positive correlation existed between syrinx length and neurological deterioration whereas the cyst diameter did not seem to be of importance.

(4) Each syrinx started at the level of the initial cord injury.

(5) The cord appearance at the level of the cyst was either atrophic or enlarged.

\section{MANAGEMENT OF PTS}

Thirteen patients were treated conservatively (three refused an operation) and seven surgically. Table 3 gives the overall findings for the 13 non-operated patients.

Surgical treatment consisted of inserting a $T$ tube draining into the subarachnoid space without closure of the dura in three patients. Syringostomia and restabilisation of the spine were carried out each in two patients. Table 4 summarises the relevant clinical and radiological details of the seven patients. The indications for surgery were increasing loss of motor function and severe pain.

\section{Follow up during conservative treatment}

Out of the 13 patients 10 remained stable clinically with a mean follow up of 37 (range 7-56) months. Annual MRI showed no change in the expansion of the cavity (table 3 ). The other three patients who refused operations showed either new symptoms or progression of the deficit over years. The follow up period of these three patients was 30,68 , and 278 months. Annual MRI disclosed enlargement of the cavities (table 3 ).

Follow up after surgical treatment

In the seven patients treated surgically mean time between first symptoms and surgery was
70 (range 7-192) months and mean time between trauma and first complaint was 107 (range 2-324) months. Mean time between trauma and surgery was 184 (range 9-444) months. Mean follow up time since surgery was 74 (range 7 to 288) months. At short term follow up six patients showed an improvement of their symptoms whereas one remained stable (table 4). Pain disappeared in all patients but one (with Charcot-shoulder joint disease). Average time for preoperative pain was 4.5 years. Motor improvement was the most consistent sign (five out of six patients) whereas sensory disturbances improved in only three out of six patients. Evolution time of the increased motor weakness ranged from 31 to 192 (mean 80.4) months. Evolution time of the sensory deficits could not be assessed.

On early MRI studies ongoing cyst collapse could be seen in all patients but one (No 16) who became worse four years after syringostomia. Further motor and sensory deteriorations were paralleled by cyst re-expansion. In this small surgical series with a short mean postoperative follow up the possibility of later deterioration due to blockage of drains or incision closure has to be considered, as suggested by Sgouros and Williams. ${ }^{11}$

\section{Discussion}

This study aimed at evaluating the incidence, clinical signs, and outcome of PTS in 449 patients with post-traumatic paraplegia and tetraplegia. Although the classic definition of syringomyelia applies to "longitudinal cavities within the spinal cord that extend over several segments" as mentioned in Greenfield's text book, quoted by Sgouros and Williams, ${ }^{11}$ in our series the term syringomyelia was based on clinical and radiological signs of syrinx, independent of size. Five patients displayed PTS signs with the involvement of one single segment (table 2). Of our patients admitted between 1 January 1987 and 31 December 1993, 4.45\% displayed PTS symptoms. Other reported percentages range from 0.3 to $3 \cdot 2 \%{ }^{6{ }^{12}}$ Better knowledge of PTS and especially more frequent use of MRI should explain this increase in incidence. The disease was found more often in patients with complete paralysis (16 out of 20 patients) as reported by Rossier et $a l^{\circ}$ in contradiction to other authors' findings. ${ }^{131+}$ As mentioned in the medical literature the first symptoms of PTS in our patients occurred as early as two months and as late as 30 years after injury. ${ }^{015}$ 


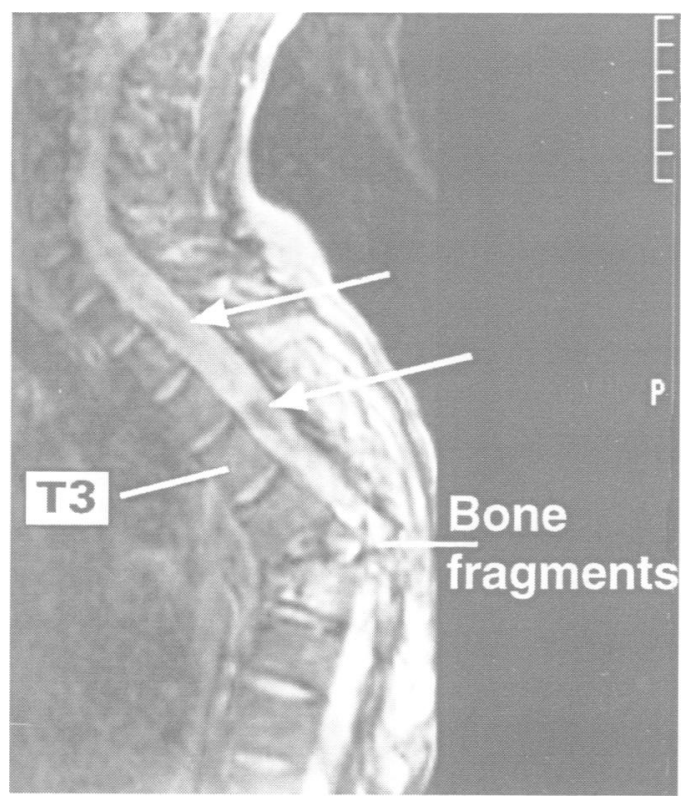

Figure 1 Case No 2, a 37 year old patient with complete paraplegia Th4 bilaterally. First T2 weighted MRI (TR 2020, echo width $50 \mathrm{~ms}$ ) carried out one year after injury immediatly after the appearance of the first clinical PTS signs. Right paramedian sagittal cut. Irregular shaped hypodensities (arrows) within the hyperintense $C S F$ is caused by strong CSF pulsations.

Necropsies have shown that morphological changes similar to those described in PTS may take place in the early post-traumatic period. ${ }^{16} 17$ Immediate post-traumatic cavitation occurred only in the very few patients with cord transsection. It was never seen in the very early stage of partial necrosis of the spinal cord. ${ }^{16}$ Despite the small number it seems that completely tetraplegic patients exhibit a longer mean interval between initial trauma and progressive PTS signs. This is at variance with some authors who did not find any significant differences in the level and completeness of the lesion. ${ }^{141819}$

Other authors have found that pain was the most common initial sign, ${ }^{6182021}$ and it was

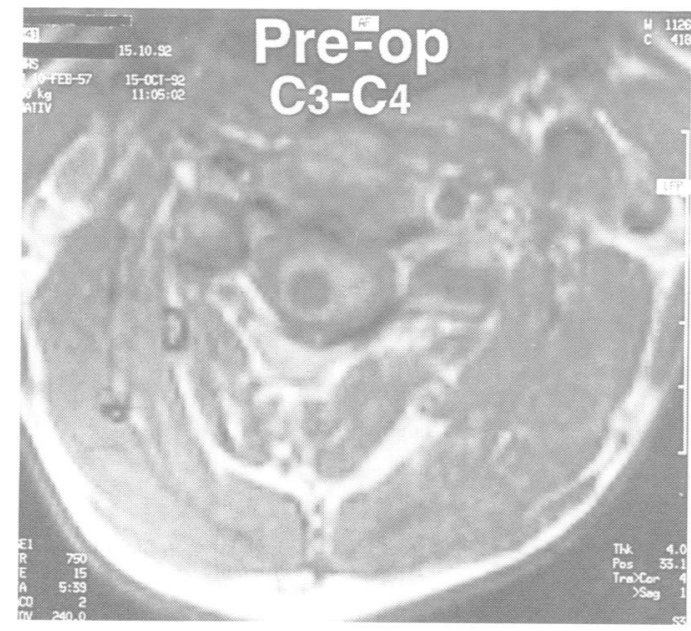

A present in $60 \%$ of our patients. The major clinical finding in this study was that only $50 \%$ of patients displayed an ascending sensory level. This finding is at variance with those of Rossier $e t a l^{6}$ and Vernon, ${ }^{18}$ of $93 \%$ and $97 \%$ respectively. An ascending sensory level was never found as a single early manifestation but was always associated with decreased deep tendon reflexes. Motor weakness, which has been reported as a late manifestation, was never present as an isolated sign. ${ }^{18}$ In our patients regular checkups leading to earlier PTS diagnosis could explain why only half of them displayed sensory disturbances. Spasticity was found to be an early and isolated clinical sign in $30 \%$ of our patients whereas Backe et al reported that it was the only clinical symptom to signal the presence of a cyst. ${ }^{7}$ Findings from MRI were usually in line with the clinical symptoms. Worsening of the symptoms, especially the motor deficit, was closely related to an enlargement of the cyst. On the other hand all patients who remained stable did not show any change in the size of the cyst in any of the MRI tests. Moreover, in the operated patients improvement or stabilisation of the symptoms was always paralleled by collapse of the cyst whereas deterioration was linked to its reenlargement.

Most authors consider that the indication for surgical treatment should be progressive neurological deterioration..$^{22-24}$ In our study the indications for surgical treatment were progressive muscle weakness, or severe pain, or both. Our findings disclosed the possible occurrence of deterioration within a mean time of six years after the appearance of the first PTS symptoms. In all patients MRI pointed to onset of PTS at the fracture site. This finding

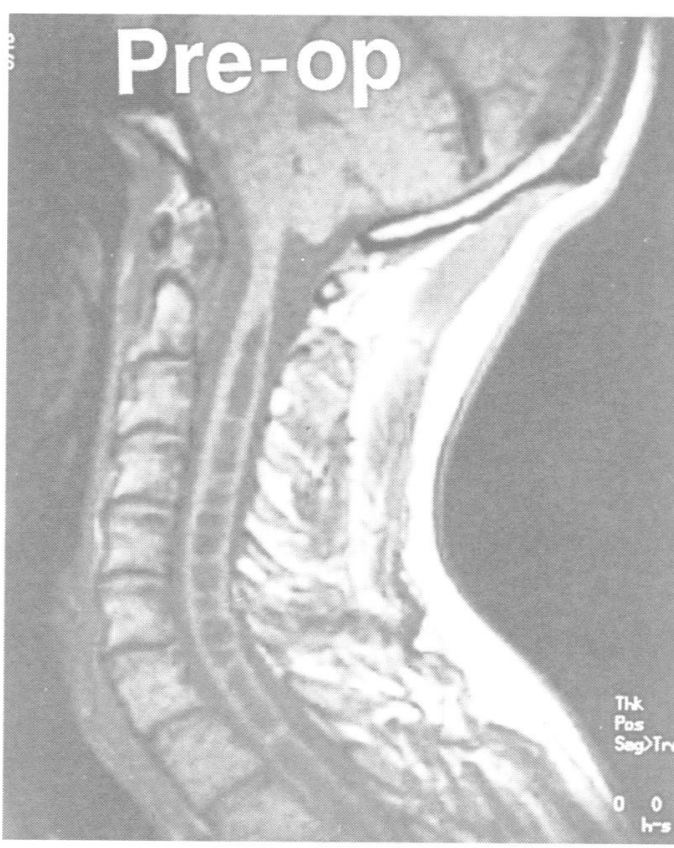

$B$

Figure 2 (A) Case No 2; same patient as recorded in fig 1. Second T1 weighted MRI (axial) carried out five years after injury and four years after the appearance of the first clinical PTS signs: ascending sensory level $C 2-C 3$ on the right. The syrinx can be seen located mainly on the right side of the cord. (B) Same preoperative T1 weighted MRI (sagittal). The intramedullary cavity seems to be multiseptated. It extends up to the C1-C2 level. 
Figure 2 (C) Case No 2. Same preoperative $T 1$ weighted MRI (sagittal): there are burst fractures of $T 5$ and T6 with wedge fracture of T7. Mid-dorsal kyphosis is pronounced $\left(69^{\circ}\right.$ $v$ max normal angle by $\left.14^{\circ}\right)$. The syrinx can be seen extending upwards and downwards from the original spine injury. There seem to be multiple septa. (D) Third T1 weighted $M R I$ (sagittal) carried out three months after surgical decompression of the cord and realignment of the spine with stabilisation by pedicle screw fixation. There was no surgical drainage of the cyst. Realignment of the spine is obvious. There is artefactual imaging secondary to the metallic fixation of the spine and collapse of the cystic cavities with decreased spinal cord enlargement all along the dorsal spinal cord below the original site of injury.

(E) Case No 2. Fourth T1 weighted MRI (axial) carried out six weeks later. Remnants of the collapsed cyst can hardly be seen. (F) Case No 2. Same postoperative $T 1$ weighted $M R I$ (sagittal): there is collapse of the cervical and upper dorsal cavities with decrease of the spinal cord enlargement.
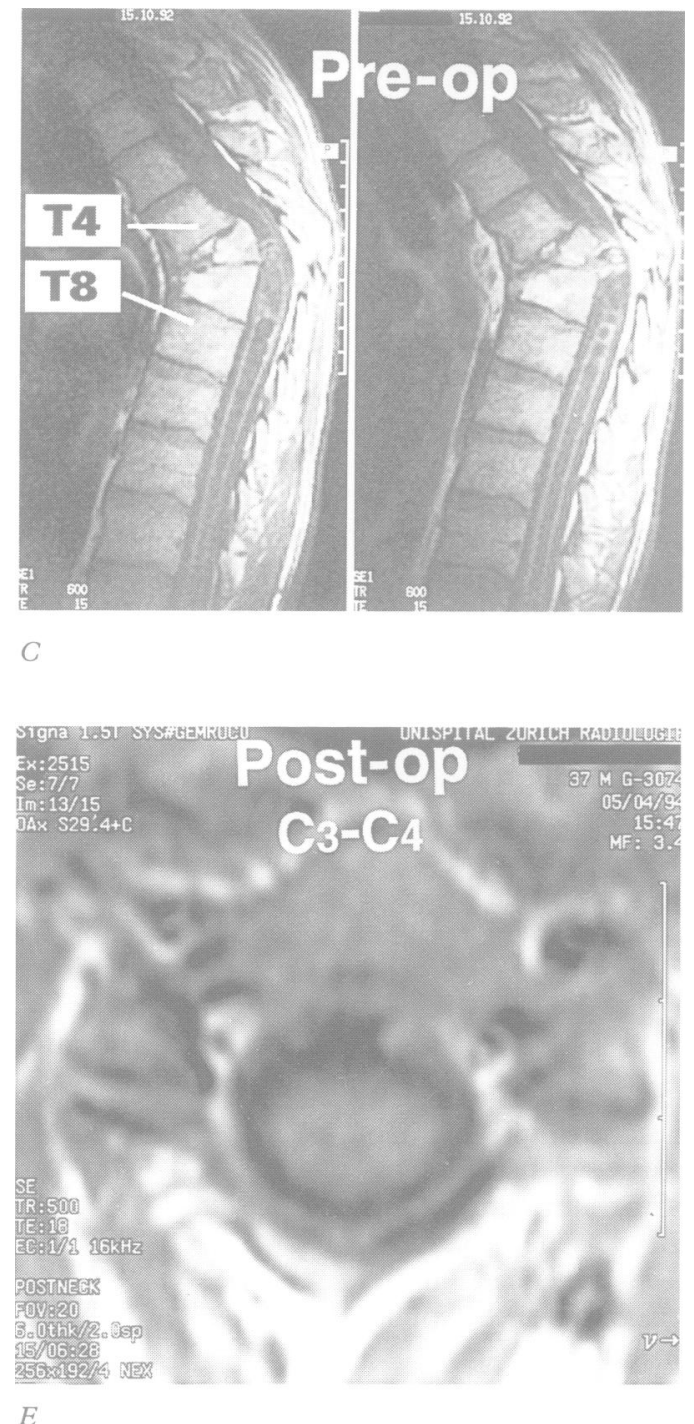

underlines the role of the complex remodelling process of the initial core as a basic causal factor leading to cyst formation. Degeneration of the initial lesion with subsequent increase of pressure within the myelomalacic core, ${ }^{325}$ haemorrhagic cord necrosis, ${ }^{26}$ haematoma liquefaction, ${ }^{2027} 28$ tissue remodelling secondary to cellular enzymes-lysosomes, ${ }^{29}$ oedema, ${ }^{30}$ or ischaemia secondary to local arachnoiditis ${ }^{31} 32$ have been suggested as potential mechanisms underlining PTS.

Late deterioration and worsening of the neurological functions have been attributed to enlargement of the $\mathrm{cyst}^{56}$; CSF may enter the syrinx through the enlarged Virchow-Robin space ${ }^{33} 34$; and PTS rarely communicates with the fourth ventricle or with the subarachnoid space at the fracture site. ${ }^{35}$

It has been shown by Williams et $a l^{36}$ that intraspinal cavities were affected by a rapid movement of CSF within them as shown in fig 1 . Increase of the intraspinal pressure by a forced expiratory effort through a closed glottis causing rapid impulsive intraspinal fluid movement alone ("slosh" phenomenon) and the pulling open of the cord tissue boarding the periphery of the cavity ("suck" mechanism) have also been described.

Deterioration of PTS after lifting heavy
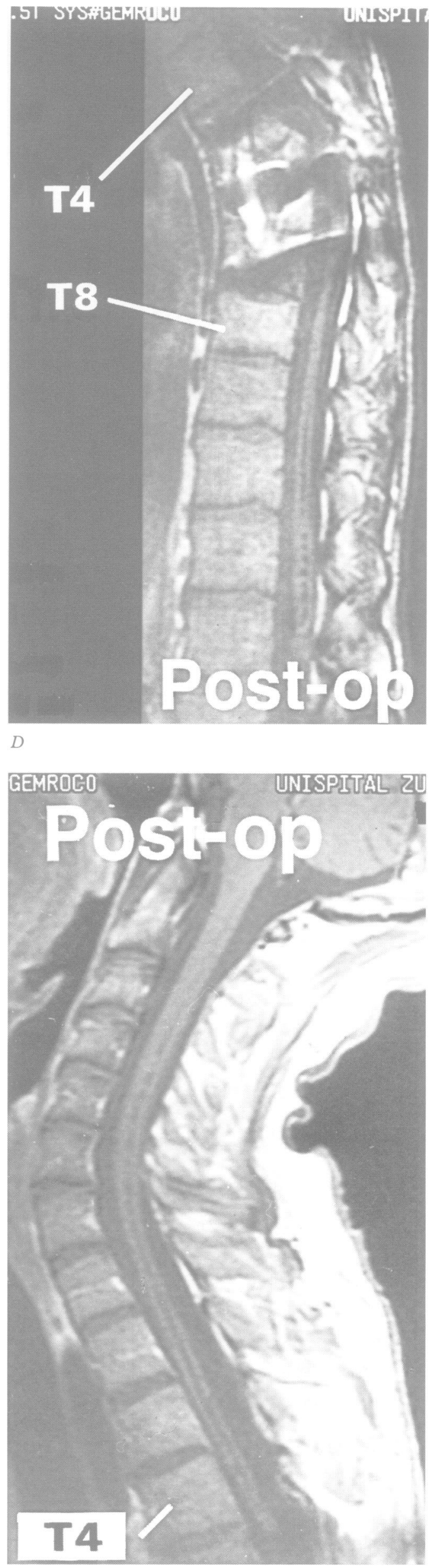
weights, ${ }^{38}$ straining, ${ }^{39}$ and even transmission of shock waves during lithotripsy ${ }^{40}$ have been reported. All of these findings point to a major role for intraspinal and intramedullary hydrodynamic factors.

In two of our patients surgical realignment of the spine that re-established a more normal free circulation of CSF was followed by a complete collapse of the cyst (fig 2). This finding supports the theory that enlargement of the cyst could be secondary to disturbances of the normal CSF flow within the subarachnoid space. ${ }^{11+1}$

The findings that neurological worsening was always associated with simultaneous cord compression at the fracture site, tense syrinx, and kyphosis suggested a major role for increased intramedullary pressure in cyst expansion. Neck flexion has been found to be associated with an increase in intramedullary pressure. ${ }^{42}$ It follows that non-operated patients with kyphosis, cord compression, and tense syrinx at the fracture site could deteriorate. In patients with acute spinal cord injury it still remains to be shown whether operative procedures aiming at re-establishing the spinal alignment will result in an improvement in the neurological deficits. Looking at our radiographs and MRI findings in PTS that pointed to the major part played by the kyphosis in the enlargement of the initial myelomalacic core it seems reasonable to assume that surgical procedures during the acute stage of the spinal cord injury could tend to decrease the risk of development of PTS. As the initial development of PTS seems to be due to vascular changes, necrosis, and secondary damage within the spinal cord their prevention in the early post-traumatic period should represent a major therapeutic goal.

\section{Conclusion}

The new findings presented here point to the apparent closed intertwining between cord compression, tense syrinx, and kyphosis at the fracture site leading to the enlargement of the syrinx and further neurological deterioration. Other studies are needed to confirm these findings before early re-alignment and stabilisation are considered as preventive steps in the development of PTS. We extend our grateful thanks to Professor A Valavanis, chief
of the Department of Neuroradiology, University Hospital, Zurich, Switzerland, for advice and comments on the reading of some MRI findings. This work was partially funded by the International Institute for Research in Paraplegia, Switzerland
(P17/93).

1 Bastian HC. On a case of concussion-lesion with extensive secondary degeneration of the spinal cord. Proceedings of the Royal Medical and Chirurgical Society of London 1867 50:499.

2 Strümpell A. Beiträge zur Pathologie des Rückenmarks. Archiv für Psychiatric und Nervenkrankheiten 1880;10 676-717.

3 Holmes G. On the spinal injuries of warfare. Goulstonian Lectures $B M \mathcal{F}$ 1915;2:760-74.

4 Freemann LW. Ascending spinal paralysis: case presentation. $\mathcal{F}$ Neurosurg 1959;16:120-2.

5 Barnett HJM, Jousse AT. Syringomyelia as a late sequel to traumatic paraplegia and quadriplegia. Clinical features. In: Barnett HJM, Foster JB, Hudgson P, eds. Syringomyelia. Philadelphia: WB Saunders, 1973:129-53.

6 Rossier AB, Foo D, Shillito J, Dyro FM. Posttraumatic cer- vical syringomyelia Brain 1985;108:439-61

7 Backe HA, Betz RR, Mesgarzadeh M, Beck T, Clancy $M$ Posttraumatic spinal cord cysts evaluated by magnetic resonance imaging. Paraplegia 1991;29:607-12.

8 Vernon JD, Silver JR, Symon L. Post-traumatic syringomyelia: the results of surgery. Paraplegia 1983;21:37-46.

9 Anderson NE, Willoughby EW, Wrightson P. The natural history of syringomyelia. Clin Exp Neurol 1986;22:71-80.

10 Stagnara P. Spinal deformity. London: Butterworths 1988: $31-2$.

11 Sgouros S, Williams B. A critical appraisal of drainage in syringomyelia. F Neurosurg 1995;82:1-10.

12 Barnett HJM, Botterell EH, Jousse AT, Wynn-Jones $M$ Progressive myelopathy as a sequel to traumatic paraplegia. Brain 1966;89:159-75

13 Griffiths ER, McCormick CC. Post-traumatic syringomyelia (cystic myelopathy). Paraplegia 1981;19:81-8.

14 Quencer RM, Green BA, Eismont FJ. Posttraumatic spinal cord cyst. Clinical features and characterization with metrizamide computed tomography. Radiology 1983;146: 415-23.

15 Barnett HJM. Syringomyelia consequent on minor to moderate trauma in major problems in neurology. In: Barnett HJM, Foster JB, Hudgson P, eds. Syringomyelia Philadelphia: WB Saunders 1973: 129-53.

16 Wozniewicz B, Filipowicz K, Swiderska SK, Deraka K Pathophysiological mechanism of traumatic cavitation of spinal cord. Paraplegia 1983;21:312-7.

17 Squier MV, Lehr RP Post-traumatic syringomyelia. 7 Neurol Neurosurg Psychiatry 1994;57:1095-8.

18 Vernon JD, Silver JR, Ohry A. Posttraumatic syringomyelia. Paraplegia 1982;20:339-64.

19 Shannon N, Symon L, Logue V, Cull D, Kang J, Kendall $B$. Clinical features, investigations and treatment of postraumatic syringomyelia. $\mathcal{F}$ Neurol Neurosurg Psychiatry 1981;44:35-42

20 Dworking GE, Staas WE. Postraumatic syringomyelia. Arch Phys Med Rehabil 1985;66:329-31.

21 Reddy KV, Del Biglio MR, Garnette EP, Sutherland R. Ultrastructure of the human posttraumatic syrinx. Neurosurg 1989;71:239-43.

22 Tator CH, Meguro K, Rowed DW. Favorable results with syringosubarachnoid shunts for treatment of syringomyelia. $₹$ Neurosurg 1982;53:517-23.

23 Peerless SJ, Durward OJ. Management of syringomyelia: a pathophysiological approach. Clin Neurosurg 1983;30: 531-76.

24 Biyani A, El Masry WS. Post-traumatic syringomyelia: a review of the literature Paraplegia 1994;32:723-31.

25 Jensen F, Reske-Nielsen E. Post-traumatic syringomyelia. Review of the literature and two new autopsy cases. Scand F Rehab Med 1977;9:35-43.

26 Leys D, Petit H, Lesoin F, Combelles G, Jomin M Syndromes syringomyéliques tardifs. Théories pathogéniques à propos de trois observations. Acta Neurol Belg 1986;86:11-19.

27 Kakulas BA. Pathology of spinal injuries. Central Nervous System Trauma 1984;1:117-26.

$28 \mathrm{La}$ Haye PA, Batzdorf U. Posttraumatic syringomyelia. West 7 Med 1988;148:657-63.

$29 \mathrm{Kao}$ C. The mechanisms of spinal cord cavitation following spinal cord transsection. Part I: a correlated histochemical study. Part II: electron microscopic observation. study. Part II: electron microscopic
Neuropathol Exp Neurol 1977;36:140-56.

30 Feigin I, Ogata J, Budzilovich G. Syringomyelia. The role of edema in its pathogenesis. $\mathcal{f}$ Neuropathol Exp Neurol 1971;30:216-32.

31 Cho KH, Iwasaki Y, Iamamura $\mathrm{H}$, Hida $\mathrm{K}$, Abe IH. Experimental model of posttraumatic syringomyelia. Preand postoperative studies. Paraplegia 1985;80:133-9.

32 Brammah TB, Jayson MIV. Syringomyelia as a complication of spinal arachnoiditis. Spine 1994;22:2603-5.

33 Ball MJ, Dayan AD. Pathogenesis of syringomyelia. Lancet 1972;i:799-801.

34 Bertrand G. Dynamic factors of syringomyelia and syringobulbia. Clin Neurosurg 1972;20:322-33.

35 McLean DR, Miller JDR, Allen PBR, Ezzeddin SDA Postraumatic syringomyelia. f Neurosurg 1973;39 P85-92.

36 Williams B, Terry AF, Jones HWF, McSweeney $T$ Syringomyelia as a sequel to traumatic paraplegia. Paraplegia 1981;19:67-80

37 Williams B. Progress in syringomyelia. Neurol Res 1986;8: $130-45$

38 Balsameda MT, Wunder JA, Gordon C, Cannell CD. Posttraumatic syringomyelia associated with heavy weightlifting exercises: case report. Arch Phys Med Rehabil 1988;69:970-2

39 Horenstein S. Intramedullary cyst formation with progressive gliosis (traumatic syringomyelia) following spinal cord injury. Transactions of the American Neurological Association 1970;95:263-6.

40 Lorenzo ND, Maleci A, Williams BM. Severe exacerbation of post traumatic syringomyelia after lithotrispsy. Paraplegia 1994;32:694-6.

41 Oldfield EH, Muraszko K, Shawker TH, Patronas NJ. Pathophysiology of syringomyelia associated with Chiari I malformation of the cerebellar tonsils. Implications for I malformation of the cerebellar tonsils. Implications

42 Tachibana S, Kitahara Y, Lida H, Yada K. Spinal cord intramedullary pressure. A possible factor in syrinx
growth. Spine 1994;19:2174-9. 